Radar Homing Guidance for Tactical Missiles 
Other Macmillan titles of related interest

Modern Communication Systems, Second Edition, R. F. W. Coates

An Introduction to the Analysis and Processing of Signals, Paul A. Lynn

Introduction to Control Theory, S. A. Marshall

Introduction to Digital Filters, Trevor J. Terrell 


\title{
Radar Homing Guidance for Tactical Missiles
}

\author{
D.A. James \\ formerly Principal Lecturer in Electronics \\ Royal Military College of Science \\ Shrivenham
}

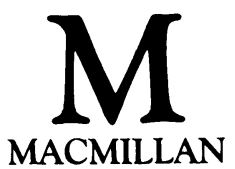


() D. A. James 1986

Softcover reprint of the hardcover 1st edition 1986 978-0-333-40977-0

All rights reserved. No reproduction, copy or transmission of this publication may be made without written permission.

No paragraph of this publication may be reproduced, copied or transmitted save with written permission or in accordance with the provisions of the Copyright Act 1956 (as amended).

Any persan who does any unauthorised act in relation to this publication may be liable to criminal prosecution and civil claims for damages.

First published 1986

Published by

MACMILLAN EDUCATION LTD

Houndmills, Basingstoke, Hampshire RG21 2XS

and London

Companies and representatives

throughout the world

British Library Cataloguing in Publication Data

James, D. A.

Radar homing guidance for tactical

missiles.

1. Guided missiles - Control systems

I. Title

623.4'519 UG1310

ISBN 978-1-349-08604-7 ISBN 978-1-349-08602-3 (eBook)

DOI 10.1007/978-1-349-08602-3 


\section{Contents}

Preface

viii

Glossary of terms $x$

List of symbols xiii

List of abbreviations $x v$

1 Basic principles 1

1.1 Introduction 1

1.2 The homing process 3

$\begin{array}{lll}1.3 & \text { A note on tracking radar } & 6\end{array}$

$\begin{array}{lll}1.4 & \text { Types of homing } & 10\end{array}$

$\begin{array}{lll}1.5 & \text { Examples of radar homers } & 13\end{array}$

$\begin{array}{lll}1.6 & \text { Operational sequences } & 19\end{array}$

$\begin{array}{ll}\text { References } & 20\end{array}$

2 Types of radar transmission $\quad 22$

$\begin{array}{ll}2.1 \text { Introduction } & 22\end{array}$

$\begin{array}{lll}2.2 & \text { Pulse } & 23\end{array}$

$\begin{array}{lll}2.3 & \text { CW-Doppler } & 24\end{array}$

3 Range performance $\quad \mathbf{3 0}$

$\begin{array}{ll}3.1 & \text { Introduction } \\ 3.2 & 30\end{array}$

3.2 Active homing $\quad 32$

$\begin{array}{lll}3.3 & \text { Semi-active homing } & 33\end{array}$

3.4 Choice of wavelength 34

$\begin{array}{ll}\text { References } & 37\end{array}$

4 Seeker antenna systems $\quad 38$

$\begin{array}{lll}4.1 & \text { Introduction } & 38\end{array}$

4.2 Amplitude comparison 38

4.3 Phase comparison monopulse 41

4.4 Interferometer systems 43

$\begin{array}{lll}4.5 & \text { Phased arrays } & 47\end{array}$

4.6 Angle tracking precision - a comparison 47 
$\begin{array}{lll}4.7 & \text { Multiplexing } & 50\end{array}$

4.8 Radomes $\quad 50$

References $\quad 55$

5 Principles of Doppler homing guidance 56

5.1 Introduction $\quad 56$

5.2 Doppler frequency spectra $\quad 56$

$\begin{array}{ll}\text { References } & 61\end{array}$

6 CW-Doppler guidance technology 62

$\begin{array}{lll}6.1 & \text { Introduction } & 62\end{array}$

6.2 Late narrow-banding receivers - explicit Doppler extraction 63

6.3 Doppler selection and tracking 65

$\begin{array}{lll}6.4 & \text { Implicit Doppler extraction } & 72\end{array}$

$\begin{array}{lll}\text { 6.5 Generation of false target signals by spurious noise modulation } & 73\end{array}$

$\begin{array}{lll}6.6 & \text { Early narrow-banding or inverse receivers } & 74\end{array}$

$\begin{array}{lll}\text { 6.7 Complete guidance receiver } & 76\end{array}$

$\begin{array}{lll}6.8 & \text { Rear reference and the illuminator } & 78\end{array}$

6.9 Rocket motor flame effects on microwave transmissions $\quad 80$

$\begin{array}{lr}6.10 \text { Initial acquisition of the target } & 83\end{array}$

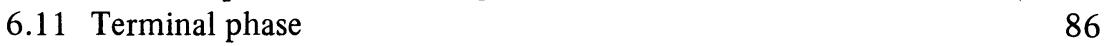

6.12 Electronic counter-measures (ECM and ECCM) 91

$\begin{array}{ll}\text { References } & 94\end{array}$

7 Pulse-Doppler $\quad 96$

$\begin{array}{lll}7.1 & \text { Introduction } & 96\end{array}$

7.2 Choice of PRF 96

$\begin{array}{llr}7.3 & \text { High PRF seekers } & 97\end{array}$

$\begin{array}{lll}7.4 & \text { Medium PRF seekers } & 100\end{array}$

$\begin{array}{lll}7.5 & \text { Radar digital signal processing } & 103\end{array}$

$\begin{array}{ll}\text { References } & 104\end{array}$

8 Radar homing on surface targets $\quad 106$

$\begin{array}{lll}8.1 \text { Introduction } & 106\end{array}$

$\begin{array}{lll}8.2 & \text { Sea targets } & 107\end{array}$

$\begin{array}{lll}8.3 \text { Land targets } & 111\end{array}$

$\begin{array}{lll}8.4 & \text { Radiometer or passive homing } & 114\end{array}$

$\begin{array}{lll}8.5 & \text { Anti-radar missiles (ARM) } & 117\end{array}$

$\begin{array}{lll}8.6 & \text { ECM } & 123\end{array}$

$\begin{array}{ll}\text { References } & 125\end{array}$

9 Future developments $\quad 128$

$\begin{array}{lll}9.1 \text { Introduction } & 128\end{array}$

$\begin{array}{lll}9.2 & \text { Digital signal processing } & 128\end{array}$ 
9.3 Millimetre-wave technology

9.5 Microwave solid state sources

9.6 Radome technology

9.7 Summary

Appendix A: Derivation of $\mathrm{k}$ for phase comparison seeker

Appendix B: Generation of false target signals in $C W$ homing missile receivers by spurious noise modulation

Appendix C: Fast Fourier transform

Index 


\section{Preface}

This book has its origin in a package of lectures given over a span of many years to the students of the Guided Weapons M.Sc. Course at the Royal Military College of Science, Shrivenham; the lectures formed part of a course of study covering the whole of guided weapons technology. Radar homing missiles have been in service in the armed forces of various countries throughout the world for at least 30 years and have been employed in many of the armed conflicts that have taken place since the end of the Second World War. Particularly noteworthy are the use of Surface to Air missiles in the Arab-Israeli conflicts and in Vietnam, and the devastating use of the Exocet sea-skimming anti-ship missile in the recent war in the Falkland Islands.

It may be asked why radar homing guidance has been singled out for special treatment; there are other forms of radar guidance and other forms of homing. The reason is that radar homing guidance combines two unique advantages: that of homing, in which the missile is theoretically certain to guide itself towards impact with the target, and that of radar which has the ability to penetrate rain, smoke, and dust. These advantages have encouraged much effort in development and in the growth of an extensive branch of radar technology which merits a treatment of its own.

Information pertaining to this subject has hitherto been rather scattered - in articles appearing in electronic engineering periodicals, in other works as part of a more general treatment, and in unpublished memoranda of a non-confidential nature within defence organisations. The purpose of this book is to collate this information sufficiently for the benefit of engineers working in this field; it is hoped that it will also prove to be of interest to engineers concerned with other branches of radar and telecommunications.

Treatment of the subject assumes no more than a knowledge of basic radar principles. It is mainly descriptive, supported by simple mathematical analyses and practical numerical examples; so far as security permits, the descriptions relate to actual systems. The introductory chapter gives a broad outline of the subject, including a general description of the homing process, operational aspects, and a selective catalogue of radar homers. It includes also a section on the basic principles of tracking radar upon which radar homing depends. Chapters 2, 3 and 4 describe features which are common to all applications; chapters 5, 6 and 7 deal with homing against airborne targets, and chapter 8 describes homing 
against slow-moving surface targets such as ships and vehicles, and includes a section on the specialized topic of homing on to enemy radar. Electronic countermeasures, which have already proved themselves to be a significant factor in the radar war, are described in the context of the particular applications mentioned. The book includes a glossary of those terms which are, on the whole, peculiar to this subject.

In conclusion, my thanks go to Professor C. J. Harris, Head of the School of Electrical and Electronic Science, Royal Military College of Science/Cranfield, for his encouragement, advice and provision of many useful facilities; to my colleagues for the provision of material and for constructive criticism; to Karen for the typing and to Les Judd for the many diagrams. Last, but not least, I wish to thank my former students for their interest and enthusiasm, which prompted me to explore the subject in depth.

The Ministry of Defence has given approval for this book to be published. 


\section{Glossary of Terms}

All-the-way

Autonomous

Autopilot

Bistatic radar

Boost (phase)

Chaff

Conical scan

Control system

Direct clutter

Ground spike

Home-on-jam

Homing eye

Homing head

Illuminator
Use of the same system of guidance throughout missile flight.

Missile can guide itself without further assistance from parent station.

\section{See Control system.}

Transmitting and receiving antenna are at separate locations.

Initial acceleration of missile to cruising velocity; short, a few seconds at most; severe, many 10 s of $g$.

Metallized strips of paper etc., resonant at radar wavelength; intended to confuse.

Method of tracking in angle, using a single rotating antenna primary feed.

Controls the flight and attitude of the missile, usually by means of appropriate aerodynamic surfaces.

Breakthrough from transmitter (active) or rear reference (semi-active) into signal receiver; has zero Doppler shift in coherent system.

Doppler shifted signal due to ground echoes in the seeker antenna main beam.

Switching from active or semi-active to passive homing on a source of electronic counter-measure (ECM).

The seeker antenna system.

The seeker.

Transmitter providing the radiation scattered from the target as an echo; can be in the seeker (active) or at the parent station (semi-active). 
Incidence lag

Inverse receiver

LATAX

Lock-on

Mid-course guidance (phase)

Monopulse receiver

Monostatic radar

Multi-path

Phased array

Pitch

Range gate

Rear reference
Non-alignment of the missile longitudinal axis with the heading.

The Doppler shift on the target echo is transferred to the reference channel.

Lateral acceleration (abbreviation).

Commencement of steady tracking of the target in all coordinates.

A different and probably less precise form of guidance used during most of the missile flight.

Radar receiver which derives a complete set of target coordinates from each pulse echo - that is, measurements are simultaneous.

Transmitter and receiver are co-located.

Propagation of radio waves by a direct path and one or more surface-reflected paths.

Antenna in which the beam is steered electronically, without mechanical movement of the antenna.

Movement of the missile or antenna in the local vertical plane (comparable to 'elevation').

A gating pulse timed to coincide with the arrival of a pulse echo.

Direct transmission from the illuminator in semi-active homing to the missile in flight to provide synchronization.

Rear reference spillover See Direct clutter.

Resolution cell

'Space' defined by the combined resolution in all coordinates.

Roll

Rotation of the missile about its longitudinal axis.

Seeker

The radar homing guidance installation in a missile.

Sequential lobing

Sequential sampling of the signals of a monopulse angle tracking antenna; equivalent electrically to conical scan.

Squint

Terminal guidance (phase)

Threshold detector
Angle between sight line and missile longitudinal axis.

Precise guidance system taking over in the final stage of missile flight.

Detector which takes cognizance of a signal only if its 
amplitude attains a given level for a given minimum duration.

Velocity gate Narrow band filter tuned to accept the Doppler frequency of the target echo.

Yaw Movement in the local horizontal plane (comparable to 'azimuth'). 


\section{List of Symbols}

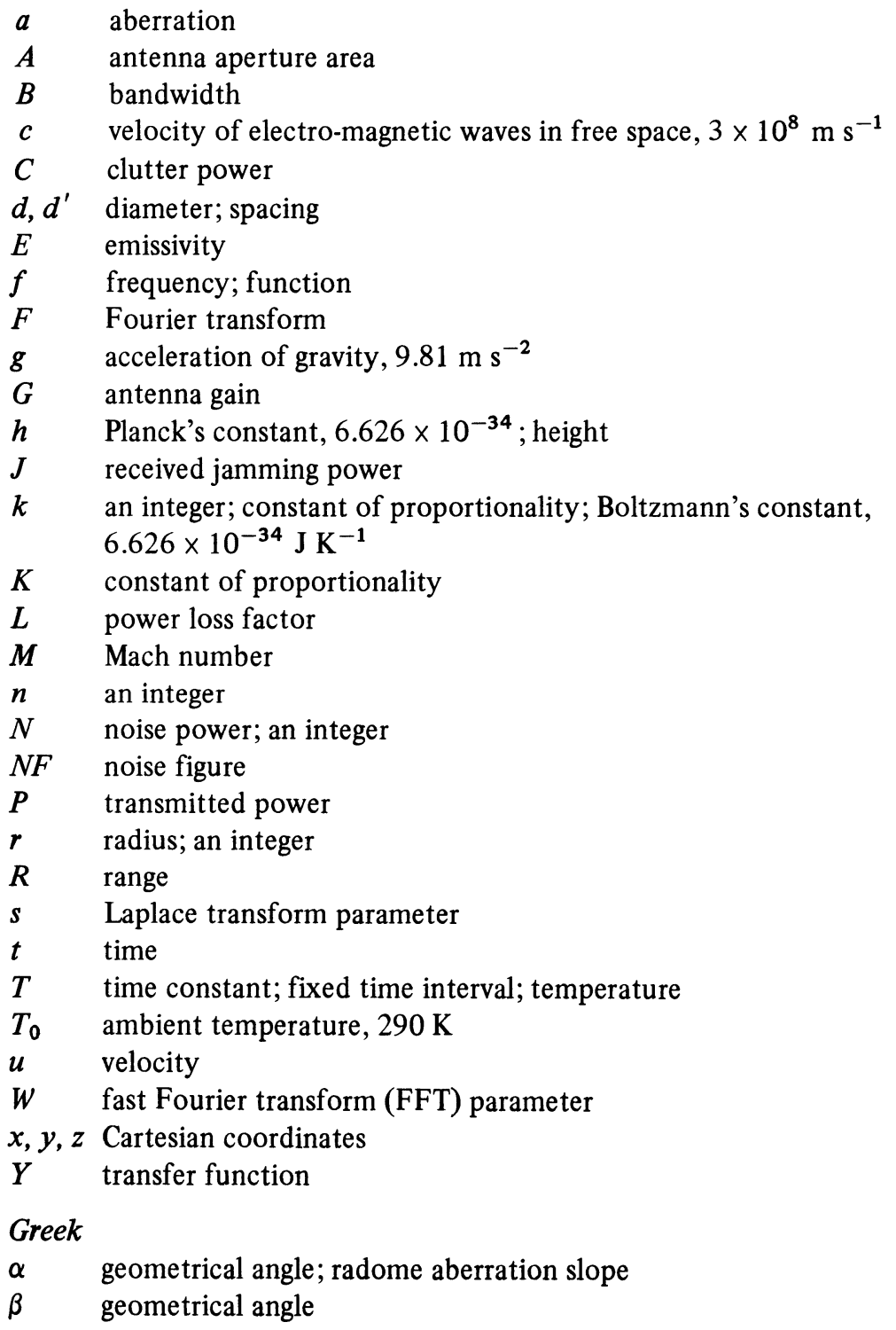


$\gamma \quad$ geometrical angle

$\delta \quad$ geometrical angle; incremental

$\tan \delta$ loss tangent

$\Delta \quad$ difference (finite)

$\epsilon$ radome aberration angle

$\epsilon_{\mathbf{r}} \quad$ relative permittivity

$\zeta$ damping parameter

$\eta \quad$ efficiency

$\theta \quad$ geometrical angle; $\theta_{3}$ antenna half-power beamwidth

$\lambda$ wavelength; proportional navigation constant

$\pi \quad 3.1418$

$\sigma \quad$ radar echoing area; standard deviation

$\sigma_{0} \quad$ radar echoing area per unit area of clutter

$\sigma^{\prime} \quad$ radar echoing area per unit area of diffusing surface

$\Sigma$ sum

$\tau$ pulse duration

$\phi \quad$ phase angle; geometrical angle

$\psi \quad$ angle with respect to space axes; geometrical angle

$\omega \quad$ angular velocity; pulsatance $(2 \pi f)$

\section{Suffixes}

a atmospheric; aberrated sight line

c carrier; rear reference spillover

C clutter

D boresight axis; Doppler

e elapsed; earth

f missile heading

g glint

i integrated

I interferometer; illuminator

J jammer

$\mathrm{m}$ missile

n natural

o local oscillator

p pitch

$r$ recurrence; receiver

$\mathbf{R}$ receiver

s target sight line; system

$\mathrm{t}$ transmitted; target

$\mathrm{T}$ target

y yaw 


\title{
List of Abbreviations
}

\author{
AAM air to air missile \\ $\mathrm{AC}$ alternating current \\ AFC automatic frequency control \\ AFV armoured fighting vehicle \\ AGC automatic gain control \\ ARM anti-radar missile \\ ASM air to surface missile \\ CS compressive strength \\ CW continuous wave \\ DC direct current \\ DFT discrete Fourier transform \\ ECCM electronic counter-counter-measures \\ ECM electronic counter-measures \\ EM electro-magnetic \\ ERP effective radiated power \\ ESM electronic support measures \\ FFT fast Fourier transform \\ FM frequency modulation \\ FMCW frequency modulated continuous wave \\ FMICW frequency modulated interrupted continuous wave \\ FS flexural strength \\ GBJ ground-based jammer \\ IF intermediate frequency \\ IFA intermediate frequency amplifier \\ LO local oscillator \\ LOS line of sight \\ MCOPS millions of complex operations per second \\ MIC microwave integrated circuit \\ PA probability of acquisition \\ PN proportional navigation \\ PRF pulse recurrence frequency \\ PSR phase-sensitive rectifier \\ RF radio frequency \\ SAM surface to air missile
}


SAW surface acoustic wave

S:N signal to noise ratio (power)

SOJ stand-off jammer

SSJ self-screening jammer

SSM surface to surface missile

TGSM terminally guided sub-munition

TIR tracking and illuminating radar

TVM target via missile

UTS ultimate tensile strength

VCO voltage-controlled oscillator

YIG yttrium-iron-garnet 